\title{
Perspectives in the Coordinate Regulation of Cell Cycle Events in Synechococcus
}

\author{
Yukio Asato \\ University of Massachusetts Dartmouth, N. Dartmouth, \\ Massachusetts 02747, USA
}

\begin{abstract}
The concepts of cell theory and the notions of coordinate regulation of the cell cycle have been known for centuries but the conundrum of coordinate regulation of the cell cycle remains to be resolved. The unique characteristics of the cell division cycle of Synechococcus, a photosynthetic bacterium, suggest the existence of a complex network of light/dark responsive gene regulatory factors that coordinate its cell cycle events. Evaluation of the highly ordered cell cycle of Synechococcus led to the construction of workable models that coordinate the cell cycle events.
\end{abstract}

A central issue in bacterial cell growth is the elucidation of the genetic regulatory mechanisms that coordinate the cell cycle events. Synechococcus, a unicellular cyanobacterium, displays a peculiar cell growth cycle. In the light growth conditions, a highly ordered and sequentially coordinated appearances of r-protein synthesis, rRNA synthesis, DNA replication, chromosome segregation, and cell septum formation occur (Figs 1, 2A). Cell membrane syntheses occur predominantly during mid-cell cycle and cell division period. Synthesis of thylakoid (=photosynthetic apparatus) is thought to occur during mid-cell cycle and coincides with a period of peak phospholipid synthesis and oxygen production (Csatorday and Horvath, 1977; Asato, 1979). Cell wall syntheses occur in short discontinuous periods throughout the cell cycle and during cell division (Asato, 1984). Distinct D1 (=G1), C (S) and D2 (=G2) periods as defined by Cooper and Helmstetter (1968) are observed in synchronized cultures of Synechococcus (Asato, 1979). When light grown cultures are placed in the dark, the ongoing cell cycles are aborted in the dark (Fig. 3A) and cell divisions do not occur (Asato, 1983; Marino and Asato, 1986). Upon re-exposure of the cell cultures to the light growth conditions, about $14 \mathrm{~h}$ later, new cell cycles are re-initiated. These characteristics of cell growth are considered to be expressions of a unique strategy of obligate phototrophic mode of growth to perpetuate their species (Asato, 2003). Nevertheless, the intermediate metabolism, the synthesis of building block molecules, the genetics and molecular biology in the formation of major macromolecules are similar to heterotrophs such as E. coli. In any case, the genes that are involved in the formation of the cellular structures and the genes that control the orderly appearances of the cell cycle events must be coordinated by novel genetic mechanisms. Currently, there are no known physiological/physical mechanisms, growth rate dependent factors or traditional genetic

For correspondence: yasato@aol.com regulatory mechanisms that could explain the coordinate regulation of the cell cycle events in bacteria (Newton and Ohta, 1992; Vinella and D'Ari, 1995; Donachie, 2001; Margolin and Bernander, 2004). Because the genetic mechanisms of coordinate regulation of cell cycle events in bacteria are largely unexplained, the questions on how Synechococcus coordinates the cell cycle events present a difficult problem to resolve. Nevertheless, the problems with regard to the coordinate regulation of the cell cycle events of Synechococcus must be considered. Possible solutions are developed and described in this article. The proposed schemes do not exclude the formation of other genetic mechanisms on the regulation of cell cycle events in Synechococcus. Although the cell cycle of Synechococcus is not widely known, the issues on the coordinate regulation of the cell cycle events are not trivial since similar regulatory mechanisms most likely occur in other prokaryotes.

\section{Issues in the coordinate regulation of the cell cycle in Synechococcus}

The characteristics of the cell cycle events, described above, indicate that the cell events are regulated by a unique genetic program. Re-analyses of the cell cycle events of Synechococcus suggest the existence of (at least) two different levels of coordinated control of cellular processes during the cell division cycle. At one level, the genes involved in carrying out the cell events

\begin{tabular}{|c|c|c|c|}
\hline \multicolumn{2}{|c|}{$D_{1}$} & $\mathbf{C}$ & $\mathbf{D}_{2}$ \\
\hline \multicolumn{4}{|l|}{$\begin{array}{l}\text { Initiation of } \\
\text { cell cycle }\end{array}$} \\
\hline \multicolumn{2}{|c|}{ r-protein } & & cell septum \\
\hline \multicolumn{4}{|c|}{ rRNA } \\
\hline & & $\begin{array}{l}\text { DNA rep } \\
\text { chromoso } \\
\text { thylakoid }\end{array}$ & gation \\
\hline
\end{tabular}

\begin{tabular}{llllcllll}
\hline 0 & 1 & 2 & 3 & $\begin{array}{c}4 \\
\text { Time, } h\end{array}$ & 5 & 6 & 7 & 8 \\
\hline
\end{tabular}

Fig. 1 Timescale in the appearances of cell cycle events during growth of Synechococcus. The complete sequential appearances of the cell cycle events are summarized elsewhere (Asato, 2003). The $D_{1}, C, D_{2}$ periods indicate the gap, synthesis, gap periods that are observed in synchronized cultures. The cell cycle events (initiation, r-protein, rRNA, DNA replication, chromosome segregation, thylakoid and cell septum formations) are considered in the regulatory schemes described in Figs 2 and 3 . The syntheses of cell membranes and cell wall could be controlled by an alternate, interdependent path (Asato, 2003) and are not included in the figure. 


\section{A. Sequential appearances of the cell cycle events in the light}

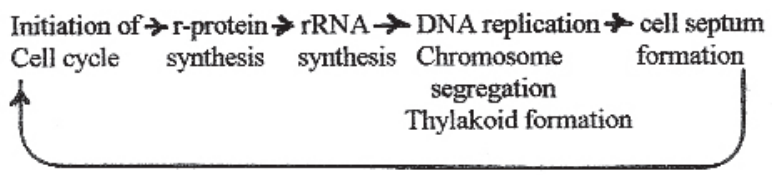

\section{B. Coordinate regulation of the cell cycle events in the light}

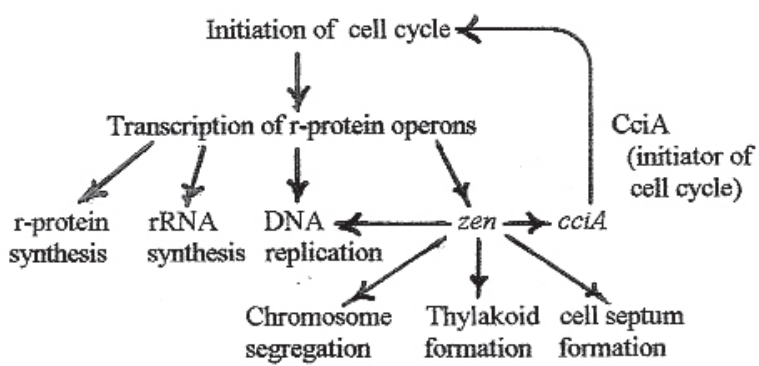

Fig. 2 A. Sequential appearances of the cell cycle events in the light. B. Coordinate regulation of the cell cycle events in the light. CciA initiates the cell cycle by activating the transcription of $r$-proteins. This critical event leads to the synthesis of r-protein, rRNA, initiation of DNA replication and the transcription of a hypothetical master gene, zen. Zen, in turn, coordinates the replication/termination of DNA molecule, chromosome segregation, thylakoid formation, cell septum formation and activates the transcription of the cell cycle initiator, cciA (gene encoding CciA).

must be under genetic control such that the transcription of the genes appear in an orderly manner. It is likely, for example, that $r$-proteins operons ( $r p s$ and $r p l$ ) would be transcribed in the order of the binding sequence of the $r$-proteins onto the nascent rRNA during the ribosome assembly process (Cowgill de Narvaez and Schaup, 1979). DNA replication involves a complex set of genes and the replication process could occupy a major time frame in the cell cycle. In Synechococcus, DNA replication takes place in a $3 \mathrm{~h}$ period within an $8 \mathrm{~h}$ cell division cycle. It is likely that the transcription of genes involved in the initiation, replication, and termination phases of DNA replication would be genetically coordinated to appear in the order of the replication phases. For example, genes involved in the initial phases of DNA replication would be transcribed several hours before the genes involved in the terminal phases of replication. It is interesting to note that in E. coli, the cell division time could be shorter than the DNA replication time. For example, when $E$. coli is grown in an enriched medium at $37^{\circ} \mathrm{C}$, the generation time could be as short as 20 min while the DNA replication is 40 min (Cooper and Helmstetter, 1968). It appears that the genes involved in the early phase of DNA replication would be transcribed in one cell division cycle and the transcription of the genes involved in the completion of the DNA replication could occur in the subsequent cell division cycle. At the other level of control, the cell cycle events must be coordinated in a way that these events occur at a specific time and space during the cell growth cycle. For example, r-protein synthesis is synthesized before rRNA synthesis during the ribosome assembly process (see Fig. 2A; Asato, 2005) and ribosome formation occurs before the initiation of DNA replication. Clearly, there are several major problems that must be addressed in determining the coordinate regulation of

\section{A. Cell cycle events uncoupled by dark incubation}

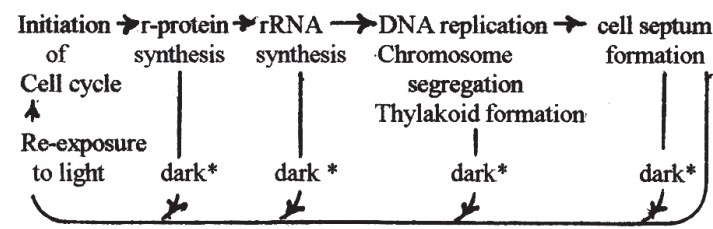

B. Dark interrupted cell cycle

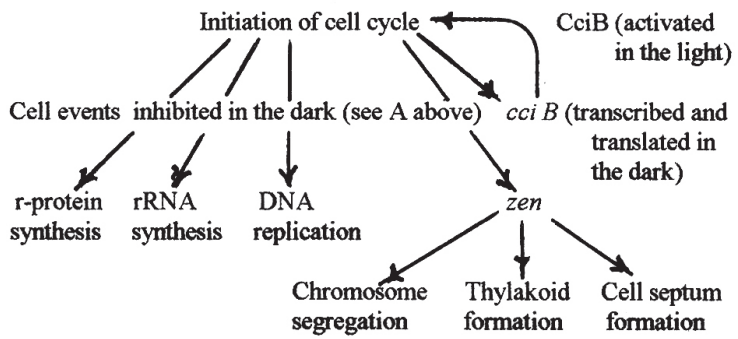

Fig. 3 A. Cell cycle events uncoupled by dark incubation. When cells that are growing in the light are placed in the dark environment (indicated by dark $^{*}$ ) the ongoing cell cycles are not completed and the cell cycles are aborted. It is highly likely that the temporal and sequential order of cell events are coordinated by a cascade of sequentially expressed, light responsive regulatory or initiator molecules. The key regulatory molecules (and possibly ancillary sigma factors) are active in the light and become inactive in the dark (see Asato, 2003). As a consequence, the ongoing cell cycles are aborted. Upon re-exposure to the light after $14 \mathrm{~h}$, new cell cycles are initiated. B. A proposed model of dark interrupted cell cycle. Ongoing cell cycles are aborted in the dark as indicated in A. cciB, the alternative initiator gene, is transcribed and translated in the dark. Upon re-exposure to the light, $\mathrm{CciB}$ is light-activated and re-initiates the cell cycle. Details of the model are described in the text.

the cell cycle events in Synechococcus. The genes or operons that are involved in carrying out the cell cycle events are widely distributed on the genome and the genes should be expressed during the execution of the cell events. On the other hand, the appearances of the cell events occur in a timely order (Fig. 2A) and each of the cell event carry out uniquely different task. Regulatory mechanisms must exist to coordinate the appearances of the functionally unrelated cell events at specific time and space. Furthermore, the regulatory factors must be light responsive entities. What are the genetic mechanisms that are able to coordinate the regulation of the cell events? Genetic analysis and model building are of great value in initiating the first step in resolving complex problems. For example, a model that describes the coordinate regulation of macromolecular synthesis periods has been useful in explaining the coordinate regulation of the macromolecular synthesis periods in Synechococcus (Asato, 1983; Asato, 2003). The major construct of the model indicates that the temporal and sequential order of macromolecular synthesis periods is coordinated by a cascade of sequentially expressed light responsive regulatory (or initiator) molecules. In support of the concept, a light-responsive transcription factor (Rbp1) of rRNA synthesis has been isolated (Asato, 1998). Rbp1 was implicated in the coordinate regulation of $r$-protein and rRNA syntheses in the formation of ribosomes (Asato, 2005). These developments support the notion that novel genetic mechanisms coordinate the orderly appearances of the cell cycle events in Synechococcus. The genetic constructs, presented below, are attempts to explain the issues of coordinate regulation of the cell cycle events 
in Synechococcus. It is likely that some of the genetic constructs described here would be applicable to other prokaryotes.

\section{Initiation of cell cycle}

Cell cycles are re-initiated at the end of the cell cycles (Fig. 2A) or when light grown cultures are placed in the dark and re-exposed to light (Fig. 3A). Soon after the initiation of the cell cycle, r-protein synthesis is first to appear followed by the cell events as indicated in the Figs $2 \mathrm{~A}$ and $3 \mathrm{~A}$. These observations poses several questions. What are the mechanisms that initiate the cell cycle soon after the end of the cell cycle or after dark incubation? How does the initiation of the cell cycle leads to r-protein synthesis and not to any other cell events? The questions present an enormously difficult problem to resolve. It is becoming clear, however, that initiation of the cell cycle is crucial in understanding the underlying genetic mechanisms that coordinate the sequential appearances of the cell cycle events. In order to answer these questions, it is necessary to propose the existence of two mutually exclusive hypothetical cell cycle initiator genes (cciA and $c c i B$ ) and a master coordinator gene, zen. The initiator gene, cciA, is activated by a versatile, hypothetical, master gene, zen, during the late D2 period. The initiator molecule CciA is light-activated and initiates the cell cycle in cells exposed to continuous light source. It should be pointed out that zen is a multi-tasking gene that coordinates the appearances of CciA, as well as, DNA replication, chromosome segregation, thylakoid formation and cell septum formation (see Fig. 2B). The master gene, zen, is operationally similar to the master gene, $\operatorname{crt} A$, in Caulobacter crescentus. crtA regulates the expression of r-protein operons, genes for DNA replication and cell division genes during the $S$ period (MacAdams and Shapiro, 2003). The proposed role and the mechanism of genetic control by zen will be described in the sections that follow. The alternative cell cycle initiator, cciB, is transcribed (constitutively?) and translated in the dark and, as a consequence, the cell cycle initiator, CciB, is produced only during dark incubation (Fig. 3B). CciB is, however, activated in the light and initiates the cell cycle as soon as the cells are exposed to a light source. Remarkably, the cell cycles that are reinitiated in this manner are reduced to one half of the normal doubling time ( $8 \mathrm{~h}$ to $4 \mathrm{~h}$ ) to complete the first round of the cell cycle upon exposure to the light (Asato, 1983). This genetic strategy optimizes cell reproduction during the relatively short daylight growth period since the dark/light transition phase is bypassed (Asato, 2003). In support for the existence of the hypothetical gene, $c c i B$, it should be pointed out that there are genes or gene functions in cyanobacteria that are active in the light and others that are active in the dark. For example, in Synechococcus PCC 8801 (strain RF-1), nif genes are transcribed in the dark but not in the light. The transcription of $r b c L$ (gene encoding a key enzyme in $\mathrm{CO}_{2}$ fixation) is transcribed in the light and not in the dark (Chow and Tabita, 1994). These findings are consistent with the finding that in a marine Synechococcus nitrogen fixation occurs in the dark in a cellular environment of low oxygen tension (Mitsui et al., 1986). In Synechococcus sp. PCC 7002, the transcription of $\operatorname{irt} A$ is repressed in the light but de-repressed in the dark; interestingly, the translation of irtA transcripts occurs in the light (Smartzidou and Widger, 1998). The unique characteristics of $\mathrm{CciB}$ in Synechococcus contributes, in part, to the property commonly known as obligate phototrophy, i.e. cells do not grow in the dark.

The troubling questions of how or what is initiated to jump-start the cell cycle must be addressed. Since the first cell event is r-protein synthesis, initiation factors CciA or $\mathrm{CciB}$ initiate the transcription of $r$-protein operons to start the cell cycle. The progression of the cell cycle following the transcription of $r$-protein operons will be described in the following sections.

\section{Coordination of r-protein and rRNA syntheses in ribosome assembly}

In Synechococcus, r-proteins are the first macromolecules synthesized soon after the initiation of the cell cycle. rRNA synthesis occurs soon after r-protein synthesis. Apparently, ribosomes would be the first internal cellular structures formed after the initiation of the cell cycle. The issues in ribosome synthesis that needs to be addressed are the genetic mechanisms that coordinate, (1) the transcription of r-protein operons and, (2) the coordinate regulation of r-protein transcription and rRNA syntheses. In the first case, the transcription of $r$-protein operons is mediated by functionally similar initiation factors, CciA or $\mathrm{CciB}$ as indicated earlier. According to the transcriptionally coupled ribosome assembly process in E. coli, r-proteins are added onto the rRNA as the nascent rRNA is being transcribed (Cowgill de Narvaez and Schaup, 1979). The r-proteins (e.g., S2, S21 etc) that bind early onto $16 S$ rRNA are found in greater concentrations in the cell, and the order of r-protein binding to rRNA is similar to the in vitro reconstitution of $30 \mathrm{~S}$ ribosome subunits (Nomura and Held, 1974). The binding of r-proteins onto the nascent rRNA determines the preliminary conformation of the 16S rRNA during transcription and protects the rRNA from being degraded by RNAase. This assembly process suggests that rps operons are transcribed before $\mathrm{rpl}$ operons. A possible mechanism in the transcription order of the r-protein operons is the existence of a promoter strength hierarchy of $r$-protein operons. That is, all r-protein operons share consensus promoter sequences with varying promoter strengths. $r$ proteins that are assembled early onto the nascent rRNA will posses r-protein operon promoter sequences that attract the binding of RNAP before others. The second regulatory event in ribosome assembly concerns the coordination of r-protein synthesis and rRNA transcription. A genetic mechanism that coordinates r-protein and rRNA syntheses in Synechococcus has been proposed and presented elsewhere (Asato, 2005). In brief, a r-protein operon contains a gene that codes for a light activated transcription factor whose function is to initiate the synthesis of rRNA in the light. The expression of r-protein operon produces r-proteins as well as a transcription factor that initiates rRNA synthesis. It should be pointed out that a transcription factor, Rbp1, has been isolated and has been found to stimulate rRNA synthesis in the light but not in the dark (Asato. 1998). Unfortunately, the genetic locus of $r b p$ has not been determined. Nevertheless, it is not unusual to find a variety of genes embedded in $r$ protein operons that are involved in RNA transcription, 
translation and DNA replication. For examples, genes coding for proteins involved in transcription $\left(\beta, \beta^{\prime}, \sigma\right.$ factor), translation factors (G, Ef-Tu, TufA, EF-Ts) and DNA replication (DnaG) are found in r-protein operons in E. coli (Lindahl and Zengel, 1986). The question of how DNA replication occurs after ribosome production will be described below.

\section{Initiation of DNA replication}

In Synechococcus, DNA replication is always initiated after the initiation of r-protein and rRNA syntheses. It is possible that the synthesis of r-protein is somehow linked to the activation of genes that are engaged in the early steps of DNA replication. Most of the genes involved in the early steps of DNA replication in E. coli would be involved in the replication of DNA in Synechococcus as well. A possible mechanism is the functional linkage of genes involved in the initial phase of DNA replication to the transcription of $r$-protein operon. Note that dnaG (DNA primase) locus is found in S21 r-protein operon in E. coli. $d n a A$ could also reside in a r-protein operon. According to this scheme, the transcription of $r$-proteins would activate the transcription of $d n a A$ and $d n a G$. Other proteins engaged in the early steps of DNA replication could be regulated by the hypothetical master gene, zen (see Fig. $2 \mathrm{~B}$ ). The mechanism of control by zen is described in the following section.

\section{DNA replication, chromosome segregation, thylakoid formation and early proteins of cell division occur concurrently at $\mathbf{C}$ period}

The $C$ period has long been considered as the phase where DNA is replicated. However, investigations of $E$. coli cell cycle indicate that DNA replication, chromosome condensation/segregation and preliminary stages of cell division occur concurrently during $\mathrm{C}$ period. In Synechococcus, thylakoid synthesis takes place during $\mathrm{C}$ period as well. The problem in deciphering the genetic mechanisms that regulate genes that occur at specific phases and perform totally different cell events has been described earlier. This dilemma arises again at this critical phase of the cell cycle. Genes involved in chromosome condensation/segregation and cell septum in $E$. coli would also be found in Synechococcus. The loci of the genes involved in the various cell events during $C$ period are widely distributed over the genome. There are no common metabolic products that can act as regulatory molecules in activating the diverse group of genes. The genes are not organized or linked in functional genetic units. A possible mechanism in the activation of the genes is by the action of initiators (or activators) that recognize a consensus sequence in the promoter regions of the participating genes. For example, DnaA boxes are found in the upstream regions of $d n a N$ (which codes for the $\beta$ subunit of DNA polymerase) and ftsA,Q,Z. As indicated earlier, the hypothetical master gene, zen, could activate key genes that are involved in DNA replication, chromosome condensation/segregation, thylakoid formation, cell division septum formation and the initiation of the cell cycle. For examples, zen could regulate the transcription of genes that encode polymerases, topoisomarases, minCDE, mreB, cell division genes, and cci. As implied earlier, genes that are activated in the initial phases of a cell event are transcribed before genes that are involved in the later phases of the cell event. Master genes such as zen could be involved in regulating the orderly expressions of the genes. However, how is the transcription of zen initiated? Two possible mutually exclusive mechanisms are proposed. (1) zen is located within a rps or $r p l$ operon. The transcription of r-protein operon containing the master gene, zen, would lead to the production of $r$-proteins and the transcription activator, Zen. (2) zen is mapped near the oriC and activated when zen is hemimethylated during replication. The mechanism of activation of zen is similar to the activation of ctrA in C. crescentus (McAdams and Shapiro, 2003). Zen is light activated, and, in the activated state, Zen* stimulates the transcription of genes that are involved in DNA replication, chromosome condensation/segregation, thylakoid formation, cell septum formation as well as the transcription of the cell cycle initiation gene, cciA. Genes activated by Zen contain consensus binding sites in the promoter region; this mechanism in the regulation of cell cycle genes is analogous to the regulation of modular functions carried out by the master gene, ctrA, in $C$. crescentus. Note that cciA regulates the re-initiation of the cell cycle. CciA, a cell cycle initiation factor, is synthesized and activated in the light during the D2 period.

\section{Cell wall and cell division septum syntheses}

Cell wall syntheses occur periodically throughout the cell cycle and during the cell division period (Asato, 1984). The regulation of the cell wall syntheses is enormously difficult to decipher since the synthesis of the cell wall occurs outside the cytoplasmic membrane. There are at least three major events that must be carried out. (1) The glycan chains are broken by autolysins. (2) The disaccharide pentapeptide building blocks are transported across the cytoplasmic membrane by bactoprenols and inserted between the severed glycan chains. (3) The peptide chains are crosslinked to adjacent gylcan chains. MurA catalyses the initial step in cell wall synthesis. Recent findings indicate that the morphogenetic proteins, MreBCD, in E. coli form a membrane-bound complex that is essential in directing the longitudinal cell wall synthesis (Kruse et al., 2005). Interestingly, ftsQAZ have been found to suppress the deletion of mreBCD operon. Because the syntheses of the cell wall and the cell division septum formation occur periodically, it is apparent that the genes that carry out cell wall synthesis must be coordinated by regulatory mechanisms as are other cell events described above. However, the extent of cell wall synthesis is correlated with the cell size. That is, cells growing exponentially in low density cell culture are generally larger than cells growing in high cell density lag phase cultures. Therefore, it could be argued that the control of cell wall synthesis could involve biophysical factors (such as critical mass, internal hydrostatic pressure, concentration of building block molecules, etc.).

Cell division septum formation involves complex sets of genes. In cyanobacteria, several genes (ftsZ,E,I. $\mathrm{Q}, \mathrm{W}, \min \mathrm{C}, \mathrm{D}, \mathrm{E}$ and sulA) implicated in cell division septum formation were identified by the application of comparative and mutational analyses (Miyagishima, et. 
al, 2005). Transposon mutagenesis yielded additional cell division genes, $c d v 1,2,3$, ftn6 and cikA. From this brief and sketchy descriptions, the coordinate regulation of cell wall syntheses, cell division septum formation and the timely transcription of the morphogenetic proteins are obviously beyond any reasonable speculation at this point.

\section{Concluding remarks}

The inquiries made in this article suggest that there must be novel genetic mechanisms that coordinate cell cycle events of Synechococcus. The models described in this article are attempts in explaining some of the critical issues of coordinate regulation of cell cycle events in Synechococcus. Obviously, the coordinate regulation of cell cycle events involves highly complex regulatory schemes and the proposed models are simplified outlines of the schemes. Nevertheless, the models are based on fundamentally critical characteristics of the cell cycle events that have engendered operationally workable genetic regulatory control mechanisms of cell cycle events that cannot be conceived otherwise. In the past, several discoveries on the molecular genetics of Synechococcus were based on fundamentally explicit experimental data and model building. For examples, the temporal genetic mapping, the repair of radiation induced DNA damage, the discovery of plasmid in Synechococcus, the characterization of the cell cycle events and the isolation of a light responsive initiation factor of rRNA synthesis were made from the ideas generated from the relatively new or old data (see Asato, 2003). In any case, the models provide perspectives on coordinate regulation of cell cycle events of Synechococcus where none presently exists. It is likely that novel genes coordinate the cell cycle events of Synechococcus but at this point the difficulty is in uncovering them. Techniques in genetics and molecular biology have been greatly advanced. Genome sequences in a variety of bacteria have been published which include the recently determined genome sequence of Synechococcus elongatus. With the use of these tools, experiments can be designed to verify or modify the major constructs of the models described in this article. Because the basic elements of the cell cycle events are common to all bacteria, it is possible that similar regulatory mechanisms could be found in other bacteria. Obviously in heterotrophic bacteria the regulatory molecules need not be light responsive molecules.

\section{Acknowledgments}

I gratefully acknowledge the fine work of Samaa Gamie in the preparation of the manuscript. Sue Asato has been very helpful in finding critical errors which were often missed by the author.

\section{References}

Asato, Y. (1979) Macromolecular synthesis in synchronized cultures of Anacystis nidulans. J. Bacteriol. 140, 6572.

Asato, Y. (1983) Dark-incubation causes reinitiation of cell cycle events in Anacystis nidulans. J. Bacteriol. 153, 1315-1321.
Asato, Y. (1984) Characterization of cell cycle events in synchronized cultures of Anacystis nidulans. J. Gen. Microbiol. 130, 2535-2542.

Asato, Y. (1998) A light-activated DNA-binding factor stimulates transcription of the $r r n A$ operon in the cyanobacterium Synechococcus sp. PCC 6301. Mol. Gen. Genet. 260, 69-74.

Asato, Y. (2003) Toward an understanding of cell growth and the cell division cycle of unicellular photoautotrophic cynobacteria. Cell. Mol. Life Sci. 60, 663-687.

Asato, Y. (2005) Control of ribosome synthesis during the cell division cycles of E. coli and Synechococcus. Curr. Issues Mol. Biol. 17, 109-117.

Chow, T.-J. and Tabita, R. F. (1994) Reciprocal light-dark transcriptional control of nif and rbc expression and light-dependent postranslation control of nitrogenase activity in Synechococcus sp. strain RF-1. J. Bacteriol. 176, 6281-6285.

Cooper, S., and Helmstetter, C.E. (1968) Chromosome replication and the division cycle of Escherichia coli $\mathrm{B} / \mathrm{r}$. J. Mol. Biol. 31, 519-540.

Cowgill de Narvaez, C. and Schaup, H.W. (1979) In vivo transcriptionally coupled assembly of Escherichia coli ribosomal subunits. J. Mol. Biol. 134, 1-22.

Csatorday, K. and Horvath, G. (1977) Synchronization of Anacystis nidulans, oxygen evolution during the cell cycle. Arch. Microbiol. 111, 245-246.

Donachie, W. D. (2001) Co-ordinate regulation of the Escherichia coli cell cycle or The Cloud of Unknowing. Mol. Microbiol. 40, 779-785.

Kruse, T., Bork-Jensen, J. and Gerdes, K. (2005) The morphogenetic MreBCD proteins of Escherichia coli form an essential membrane-bound complex. Mol. Microbiol. 55, 78-89.

McAdams, H.H. and Shapiro, L.(2003) A bacterial cellcycle regulatory network operating in time and space. Science 301, 1874-1877.

Margolin, W. and Bernander, R. (2004) How do prokaryotic cells cycle? Curr. Biol.14, R768-R770.

Marino, J.T. and Asato, Y. (1986) Characterization of cell cycle events in the dark in Anacystis nidulans. J. Gen. Microbiol. 132, 2123-2127.

Mitsui, A., Kumazawa, S., Takahashi, A., Ikemoto, H., Cao, S., and Arai, T. (1986) Strategy by which nitrogen-fixing unicellular cyanobacteria grow photoautotrophically. Nature 323, 720-722.

Miyagishima, S, Wolk,C.P. and Osteryoung, K.W. (2005) Identification of cyanobacterial cell division genes by comparative and mutational analyses. Mol. Microbiol. 56, 126-143.

Newton, A. and Ohta, N. (1992) Cell cycle regulation in bacteria. Curr. Opin. Cell Biol.4, 180-185.

Nomura, M., and Held, W.A. (1974) Reconstitution of ribosomes: studies of ribosome structure, function and assembly. In: Ribosomes. M. Nomura, A. Tisieres and P. Lengyel, eds. (Cold Spring Harbor, NY, Cold Spring Harbor Laboratory), pp. 193-223.

Samartzidou, H. and Widger, W. R. (1998) Transcriptional and posttranscriptional control of mRNA from irtA, a light-repressed transcript in Synechococcus sp. PCC 7002. Plant Physiol. 117, 225-234. 


\section{Further Reading}

Caister Academic Press is a leading academic publisher of advanced texts in microbiology, molecular biology and medical research. Full details of all our publications at caister.com

- MALDI-TOF Mass Spectrometry in Microbiology Edited by: M Kostrzewa, S Schubert (2016) www.caister.com/malditof

- Aspergillus and Penicillium in the Post-genomic Era Edited by: RP Vries, IB Gelber, MR Andersen (2016) www.caister.com/aspergillus2

- The Bacteriocins: Current Knowledge and Future Prospects Edited by: RL Dorit, SM Roy, MA Riley (2016)

www.caister.com/bacteriocins

- Omics in Plant Disease Resistance Edited by: V Bhadauria (2016) www.caister.com/opd

- Acidophiles: Life in Extremely Acidic Environments Edited by: R Quatrini, DB Johnson (2016) www.caister.com/acidophiles

- Climate Change and Microbial Ecology: Current Research and Future Trend

Edited by: J Marxsen (2016)

www.caister.com/climate

- Biofilms in Bioremediation: Current Research and Emerging Technologies

Edited by: G Lear (2016)

www.caister.com/biorem

- Microalgae: Current Research and Applications Edited by: MN Tsaloglou (2016) www.caister.com/microalgae

- Gas Plasma Sterilization in Microbiology: Theory, Applications, Pitfalls and New Perspectives Edited by: H Shintani, A Sakudo (2016) www.caister.com/gasplasma

- Virus Evolution: Current Research and Future Directions Edited by: SC Weaver, M Denison, M Roossinck, et al. (2016) www.caister.com/virusevol

- Arboviruses: Molecular Biology, Evolution and Control Edited by: N Vasilakis, DJ Gubler (2016) www.caister.com/arbo

- Shigella: Molecular and Cellular Biology Edited by: WD Picking, WL Picking (2016) www.caister.com/shigella

-Aquatic Biofilms: Ecology, Water Quality and Wastewater Treatment

Edited by: AM Romaní, H Guasch, MD Balaguer (2016)

www.caister.com/aquaticbiofilms

- Alphaviruses: Current Biology

Edited by: S Mahalingam, L Herrero, B Herring (2016)

www.caister.com/alpha

- Thermophilic Microorganisms

Edited by: F Li (2015)

www.caister.com/thermophile
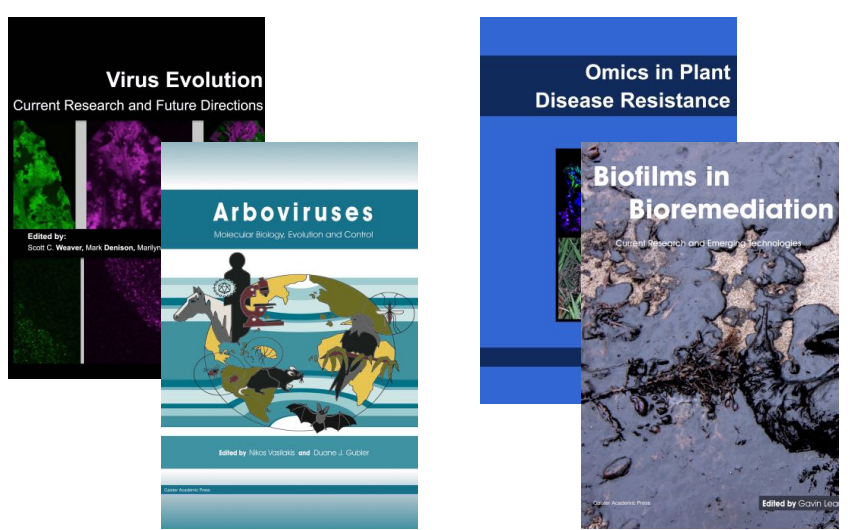
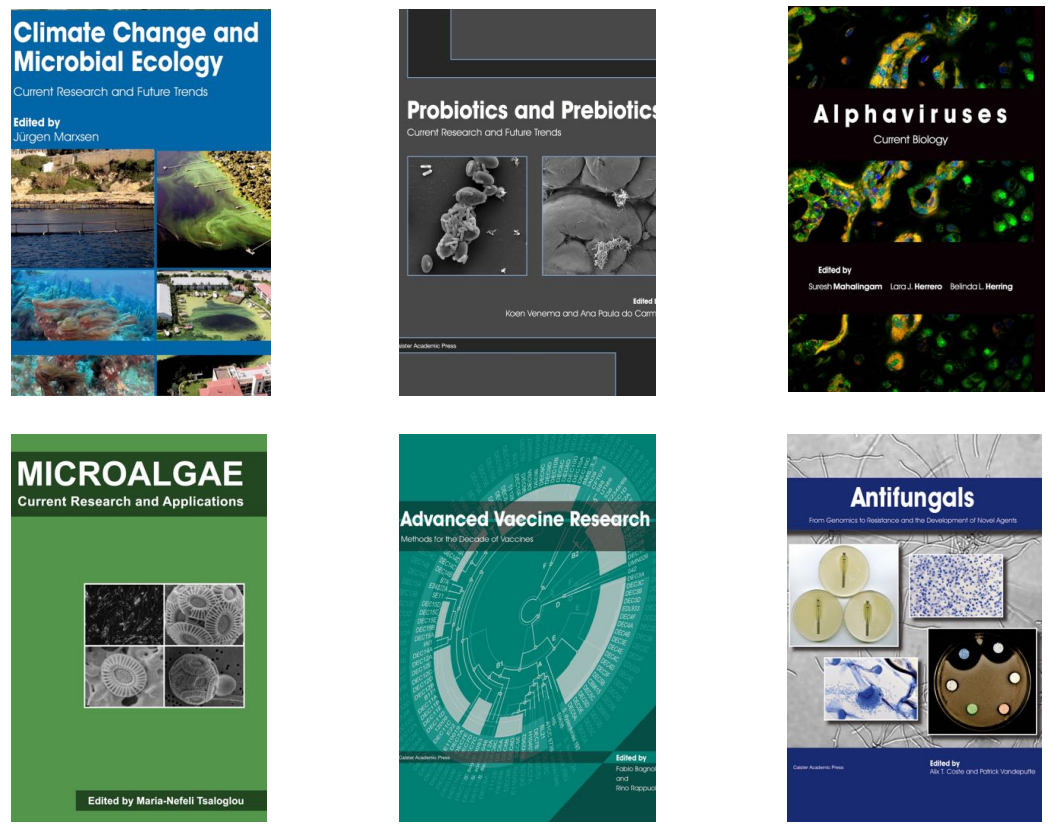

- Flow Cytometry in Microbiology: Technology and Applications Edited by: MG Wilkinson (2015) www.caister.com/flow

- Probiotics and Prebiotics: Current Research and Future Trends Edited by: K Venema, AP Carmo (2015) www.caister.com/probiotics

- Epigenetics: Current Research and Emerging Trends Edited by: BP Chadwick (2015) www.caister.com/epigenetics2015

- Corynebacterium glutamicum: From Systems Biology to Biotechnological Applications

Edited by: A Burkovski (2015)

www.caister.com/cory2

- Advanced Vaccine Research Methods for the Decade of Vaccines

Edited by: F Bagnoli, R Rappuoli (2015)

www.caister.com/vaccines

- Antifungals: From Genomics to Resistance and the Development of Novel Agents

Edited by: AT Coste, P Vandeputte (2015)

www.caister.com/antifungals

- Bacteria-Plant Interactions: Advanced Research and Future Trends Edited by: J Murillo, BA Vinatzer, RW Jackson, et al. (2015) www.caister.com/bacteria-plant

\section{- Aeromonas}

Edited by: J Graf (2015)

www.caister.com/aeromonas

- Antibiotics: Current Innovations and Future Trends

Edited by: S Sánchez, AL Demain (2015)

www.caister.com/antibiotics

- Leishmania: Current Biology and Contro Edited by: S Adak, R Datta (2015) www.caister.com/leish2

- Acanthamoeba: Biology and Pathogenesis (2nd edition) Author: NA Khan (2015)

www.caister.com/acanthamoeba2

- Microarrays: Current Technology, Innovations and Applications Edited by: Z He (2014)

www.caister.com/microarrays2

- Metagenomics of the Microbial Nitrogen Cycle: Theory, Methods and Applications

Edited by: D Marco (2014)

www.caister.com/n2 